\title{
CORRESPONDENCE
}

\section{FURTHER RENAMING OF THE TREMADOC TRILOBITE GENUS PSILOCEPHALUS SALTER}

SIR,-In the May-June number of this magazine (Stubblefield, 1951) attention was drawn to three vain attempts by previous authors to give a nomenclatorily valid name to the generic concept typified by Erinnys venulosa Salter 1872 and to Salter's earlier likewise vain attempt with his species Psilocephalus innotatus. In an effort to remedy these nomenclatorial mishaps, the names Meneviella and Psilocephalina were proposed as nomina nova. It seems, however, that the second name is also invalid for on 11th September, 1951, a copy was received in the Geological Survey Library of No. 8 of the " Contributions from the National Research Institute of Geology, Academia Sinica " which is a "Festschrift" volume to commemorate the sixtieth birthday of Professor J. S. Lee. This work has printed on its cover "November 1948 " as the date of publication. Presumably, the politically disturbed state of China has contributed to the delayed arrival in London of this volume. Among the interesting papers within its covers is one by Singwu C. Hsü (1948), in which a new genus of trilobites named $P$ silocephalina, with $P$. lubrica Hsü as type species, is described from strata in Western Hupeh stated to be of Tremadoc age. Following the generic diagnosis, Hsü (op. cit., p. 24) remarks that his new genus "bears a close kinship to Psilocephalus Salter ..... a characteristic genus occurring in the Tremadoc beds of Britain. It is similar to Salter's genus in the small anterior palpebral lobes and in the characters of the fixed cheeks and the thorax but differs in having genal spines and a wider axis of pygidium. Its free cheeks are also different in general shape from those of Salter's genus. ... It is very likely that the present genus is a vicarious form of the British genus Psilocephalus in this continent". Judging from the description and illustrations, the cranidium of the type species of Hsü's new genus is certainly morphologically similar to that trilobite which lately (Stubblefield, 1951) was referred to Psilocephalina innotata (Salter), I being unaware that the generic name had been employed by Hsü in 1948 .

Of the two available alternative courses, namely either to consider the Welsh $P$. innotata to be congeneric with the Chinese $P$. lubrica or to follow Hsü in his opinion that the species are generically distinct, the latter is here preferred. Both species belong to genera in which the obsolescence of cephalic furrows has masked those axial skeletal features usually available for comparison, so that one is hesitant to dismiss as unimportant the obvious differences in structure of the respective free cheeks. Accordingly, it is here proposed that the name Borthaspis (after Borth-y-Gest, Merioneth, the locality of the lectotype of the type species Psilocephalus innotatus) replaces the junior homonyms Psilocephalina Stubblefield (1951, p. 213) non Hsü (1948, p. 23) and Psilocephalus Salter (1866, p. 315) non Swainson (1839).

Geological Survey and Museum, C. J. STUBblefieLd.

SOUTH KENSINGTON, LONDON.

20th September, 1951.

\section{REFERENCES}

Hsü, Singwu C., 1948. Part III The I-Changian Trilobites and other Fossils in Hsü, Singwu C., and C. T. Ma, The I-Changian Formation and the I-Changian Fauna, Contrib. Nat. Research Inst. Geol. Acad. Sinica, 8, 18-46.

Salter, J. W., 1866. In Ramsay, A. C., The Geology of North Wales, Mem. Geol. Surv., vol. iii.

Stubblefield, C. J., 1951. New Names for the Trilobite Genera Menevia Lake and Psilocephalus Salter, Geol. Mag., 88, 13-4.

Swannson, W., 1839. The Natural History of Fishes, Amphibia, and Reptiles or Monocardian Animals, 2, pp. 194, 327, London. 